Article

\title{
UV Sensitization of Nitrate and Sulfite: A Powerful Tool for Groundwater Remediation
}

\author{
Yaal Lester *, Asmaa Dabash and Darine Eghbareya \\ Environmental Technologies, Department of Advanced Materials, Azrieli College of Engineering, \\ Jerusalem 9103501, Israel; asmaada@post.jce.ac.il (A.D.); dodo.che@hotmail.com (D.E.) \\ * Correspondence: yaalle@jce.ac.il; Tel.: +972-584-962-214
}

Received: 3 September 2018; Accepted: 26 October 2018; Published: 31 October 2018

\begin{abstract}
Groundwater contamination by nitrate and organic chemicals (for example, 1,4-dioxane) is a growing worldwide concern. This work presents a new approach for simultaneously treating nitrate and 1,4-dioxane, which is based on the ultra-violet (UV) sensitization of nitrate and sulfite, and the production of reactive species. Specifically, water contaminated with nitrate and 1,4-dioxane is irradiated by a UV source $(<250 \mathrm{~nm})$ at relatively high doses, to sensitize in situ nitrate and generate $\mathrm{OH} \bullet$. This leads to the oxidation of 1,4-dioxane (and other organics) and the (undesired) production of nitrite as an intermediate. Subsequently, sulfite is added at an optimized time-point, and its UV sensitization produces hydrated electrons that react and reduces nitrite. Our results confirm the effectivity of the proposed treatment: UV irradiation of nitrate (at $>5 \mathrm{mg} \mathrm{N} / \mathrm{L}$ ) efficiently degraded 1,4-dioxane, while producing nitrite at levels higher than its maximum contaminant level (MCL) of $1 \mathrm{mg} \mathrm{N} / \mathrm{L}$ in drinking water. Adding sulfite to the process after $10 \mathrm{~min}$ of irradiation reduces the concentration of nitrite without affecting the degradation rate of 1,4-dioxane. The treated water contained elevated levels of sulfate; albeit at much lower concentration than its MCL. Treating water contaminated with nitrate and organic chemicals (often detected concomitantly) typically requires several expensive treatment processes. The proposed approach presents a cost-effective alternative, employing a single system for the treatment of nitrate and organic contaminants.
\end{abstract}

Keywords: photo-sensitization; nitrate; sulfite; 1,4-dioxane; groundwater

\section{Introduction}

Dissolved water constituents can act as photosensitizers that absorb light and produce reactive species, such as the hydroxyl radical $(\mathrm{OH} \bullet)$. These photo-generated reactive species may further react and degrade organic water contaminants. Photosensitizers can be employed for water treatment, as in the case of some advanced oxidation processes (AOPs), which combine UV irradiation with hydrogen peroxide or semiconductors. Alternatively, photosensitizers such as iron, nitrate, and dissolved organic matter can be found in natural systems; where their solar light photo-generated radicals degrade organic pollutants and affect their lifetime in aquatic environments [1-3].

This study focuses on two photosensitizers, nitrate $\left(\mathrm{NO}_{3}{ }^{-}\right)$and sulfite $\left(\mathrm{SO}_{3}{ }^{2-}\right)$, and their application for groundwater treatment. The mechanism of nitrate sensitization was already identified in the late 1960s [4,5]. Nitrate irradiation with UV light (at wavelengths $<240 \mathrm{~nm}$ and $300-325 \mathrm{~nm}$ ) generates $\mathrm{OH} \bullet$ radicals, nitrite ions $\left(\mathrm{NO}_{2}{ }^{-}\right.$) (which may further photo-generate $\mathrm{OH} \bullet$ ), as well as other products such as peroxinitrite [6]. The irradiation of sulfite with UV light $(<250 \mathrm{~nm})$, on the other hand, generates reducing radicals such as hydrated electrons $\left(e_{\mathrm{aq}}{ }^{-}\right)$and sulfite radical anions $\left(\mathrm{SO}_{3} \bullet{ }^{-}\right)$, in a process commonly known as advanced reduction [7].

Despite the long-recognized mechanism of $\mathrm{OH} \bullet$ generation by photo-sensitized nitrate, only recently have researchers suggested that this process can be employed for wastewater treatment. 
Keen et al. [8] have shown that the irradiation of nitrate $(>5 \mathrm{mg} \mathrm{N} / \mathrm{L})$ with a medium pressure (MP) mercury lamp generates similar $\mathrm{OH} \bullet$ concentration as irradiating $10 \mathrm{mg} / \mathrm{L} \mathrm{H}_{2} \mathrm{O}_{2}$ (the well-known $\mathrm{UV} / \mathrm{H}_{2} \mathrm{O}_{2}$ process); thus, the combination $\mathrm{MP} \mathrm{UV} / \mathrm{NO}_{3}$ is a de facto AOP. These results were later confirmed by Lester et al. [9], who showed that the degradation rate of different organic contaminants by $\mathrm{UV} / \mathrm{H}_{2} \mathrm{O}_{2}$ (low-pressure UV lamp, $10 \mathrm{mg} / \mathrm{L} \mathrm{H}_{2} \mathrm{O}_{2}$ ) is comparable to their degradation by $\mathrm{UV} / \mathrm{NO}_{3}$ (MP UV lamp, indigenous nitrate $14 \mathrm{mg} \mathrm{N} / \mathrm{L}$ ), using a pilot wastewater treatment system.

Applying $\mathrm{UV} / \mathrm{NO}_{3}$ for groundwater treatment may be highly advantageous due to the potential use of naturally occurring nitrate. Nitrate is frequently detected in groundwater aquifers around the world [10-12], mainly as a result of intense agricultural activity [13-15]. In Israel, the average nitrate concentration in the coastal aquifer, Israel's most densely populated area, was $13.3 \mathrm{mg} \mathrm{N} / \mathrm{L}$ on 2000 [11].

Other important organic groundwater contaminants (often detected in concomitant with nitrate) include pesticides, 1,4-dioxane, and chlorinated solvents [16-18]. 1,4-dioxane (selected for this study) is frequently used as an industrial solvent, and, subsequently, is often detected at sites impacted by industrial wastewater [19]. The high solubility and low sorption of 1,4-dioxane increase the risk of groundwater contamination, following its release into the subsurface. Indeed, a large number of contaminated groundwater wells were detected in the U.S. [16], Israel, and elsewhere $[17,20]$. The International Agency for Research on Cancer and the U.S. EPA has classified 1,4-dioxane as a possible human carcinogen (B2) with a health drinking water advisory concentration of $3 \mu \mathrm{g} / \mathrm{L}$ at a $10^{-6}$ lifetime cancer risk level [21]. Although the maximum contaminant levels (MCL) for 1,4-dioxane in drinking water are not yet available, several countries have set water quality guidelines and standard levels ranging from 3 to $85 \mu \mathrm{g} / \mathrm{L}$ [19]. 1,4-dioxane is not effectively removed by conventional water treatments such as coagulation and activated carbon adsorption [22,23]; on the other hand, it was shown to be effectively degraded by (conventional) AOPs [24-26]. However, AOPs are often limited by their high operational cost (for example the cost of hydrogen peroxide; [27]). Therefore, using in situ nitrate to generate $\mathrm{OH} \bullet$ and degrade 1,4-dioxane and other organic groundwater contaminants may present an attractive cost-effective alternative for conventional AOPs.

One of the main concerns regarding UV irradiation of nitrate is the photo-generation of nitrite as a byproduct, which is a harmful contaminant with an MCL of $1 \mathrm{mg} \mathrm{N} / \mathrm{L}$-lower than nitrate. Although former studies show that nitrite level will remain well below its MCL during typical MP UV disinfection of nitrate-containing water [28], employing UV for oxidation of organic constitutes-which requires much higher UV doses-may result in elevated concentrations of nitrite. To control excess nitrite, we employed a relatively new, underexplored approach-the use of reducing radicals that degrade nitrite into harmless products. These radicals were produced by introducing sulfite into the $\mathrm{UV}$ treatment $\left(\mathrm{UV} / \mathrm{SO}_{3}\right)$ at a specific time-point. $\mathrm{UV} / \mathrm{SO}_{3}$ previously showed effective reduction of different oxidized inorganic compounds, including perchlorate, bromate and even nitrate [29-34].

The goals of this study were to: (i) evaluate the feasibility of $\mathrm{MP} \mathrm{UV} / \mathrm{NO}_{3}$ at high UV doses for the degradation of 1,4-dioxane while monitoring the concentrations of nitrate and nitrite, and (ii) propose a new sequential groundwater treatment process-UV sensitization of in situ nitrate (to oxidize 1,4-dioxane and other organics) followed by UV sensitization of (added) sulfite to reduce photo-generated nitrite. This process shows a high potential in degrading both nitrate and 1,4-dioxane, while keeping nitrite at low concentrations.

\section{Materials and Methods}

\subsection{Reagents and Chemicals}

Analytical grade ( $>98 \%$ ) 1,4-dioxane, sodium nitrate, sodium nitrite, and sodium sulfite were obtained from Sigma-Aldrich. Deionized water (resistance $=18.2 \mathrm{M} \Omega \cdot \mathrm{cm}$ ) was obtained from a Millipore Milli-Q purification system. All chemicals were used as received. 


\subsection{Experimental Setup and Procedure}

Experiments were carried out to examine (i) the efficacy of MP UV/ $\mathrm{NO}_{3}$ to degrade 1,4-dioxane and (ii) the impact of key parameters: nitrate and bicarbonate. Irradiation was performed in a temperature controlled $\left(25^{\circ} \mathrm{C}\right) 2.5 \mathrm{~L}$ glass cylindrical batch reactor (Figure 1$)$. The center of the reactor was occupied with a quartz sleeve in which a $0.45 \mathrm{~kW}$ MP UV lamp was placed vertically (Ace-Hanovia, London, UK). The average fluence-rate inside the reactor was approximately $9 \mathrm{~mW} / \mathrm{cm}^{2}$, measured using nitrate actinometry developed by Goldstein \& Rabani [35]. In a typical experiment, $2.5 \mathrm{~L}$ of buffered solution (pH 7.8) was spiked with 1,4-dioxane at $1 \mathrm{mg} / \mathrm{L}$ and sodium nitrate. The UV lamp was turned on, and sampling began after $2 \mathrm{~min}$ of lamp warmup. Samples of $5 \mathrm{~mL}$ were withdrawn at 2 min intervals and analyzed for ions and 1,4-dioxane.

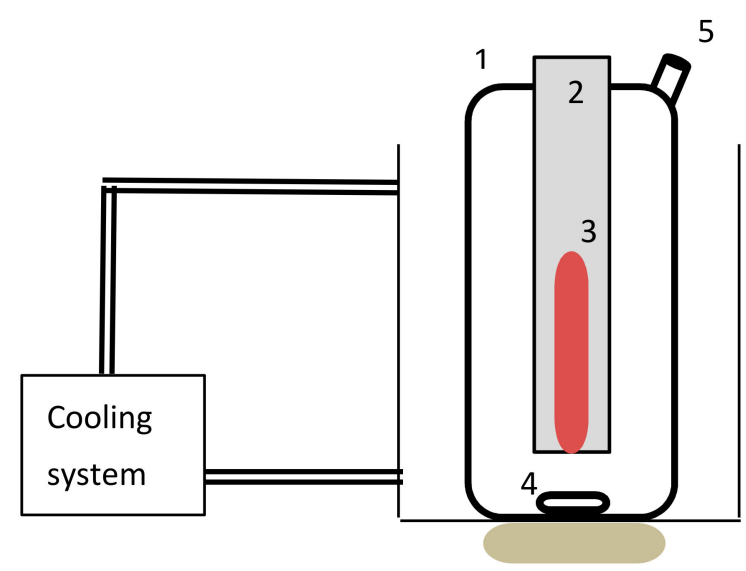

Figure 1. The schematic of the batch UV reactor: (1) reactor vessel, (2) quartz sleeve, (3) UV lamp, (4) magnetic stirrer, (5) sampling port.

\subsection{Analytical Methods}

The compound 1,4-Dioxane was measured using direct aqueous injection (DAI) [36], followed by gas chromatography (HP 6890 Series GC system, Agilent Technologies, CA, USA) coupled with a mass spectrometer (HP 5973 Mass Selective Detector, Agilent Technologies, CA, USA). The injected volume was $2 \mu \mathrm{L}$, the column was an Rtx-624 (30 $\mathrm{m} \times 0.25 \mathrm{~mm} \times 0.25 \mu \mathrm{m}$; Restek, Bellefonte PA, USA USA), and helium was used as a carrier gas. Gas chromatograph (GC) was operated under the following conditions: an injection temperature of $250{ }^{\circ} \mathrm{C}$; a total flow rate of $14 \mathrm{~mL} / \mathrm{min}$; a column flow rate of $1.3 \mathrm{~mL} / \mathrm{min}$, and split ratio of 20:1. The oven temperature was programmed from 50 (hold $2 \mathrm{~min}$ ) to $80\left(10^{\circ} \mathrm{C} / \mathrm{min}\right)$, and then to $250\left(35^{\circ} \mathrm{C} / \mathrm{min}\right)$ holding for $1 \mathrm{~min}$. The MS was equipped with an electron ionization source and set as follows: ion-source temperature: $230^{\circ} \mathrm{C}$; interface temperature: $250^{\circ} \mathrm{C}$; solvent cut time: $2 \mathrm{~min}$; MS condition-detector temperature: $150^{\circ} \mathrm{C}$, mass range: $40-250 \mathrm{amu}$, and electron energy: $60 \mathrm{eV}$. All samples were analyzed twice with a relative standard deviation of less than $5 \%$. The method detection limit (MDL) was $0.1 \mathrm{mg} / \mathrm{L}$. For the analysis of oxidation intermediates (where the lower detection limit was required), liquid-liquid extraction was performed (using dichloromethane at 1:1 v:v ratio), prior to GC injection.

Nitrate and nitrite were quantified by an ECO Ion Chromatograph (Metrohm, Switzerland), using EPA method 300.00. Ammonia was measured using the HACH salicylate method (International Standard ISO 7150). The dissolved organic matter was measured using a TOC analyzer (Torch, TeledyneTekmar, $\mathrm{OH}, \mathrm{USA}$ ) after filtering the samples at $0.45 \mathrm{~mm}$ (APHA, method 5310B). Methylene blue (MB) was used as an $\mathrm{OH} \bullet$ radical probe to measure the radicals' steady state concentration, using a method adapted from Keen et al. [8]. In brief, MB was spiked into the water at a concentration of $10 \mathrm{mM}$, and its decay was monitored spectrophotometrically at a 664-nm wavelength using a Varian Cary100Bio spectrophotometer (Agilent, Santa Clara, CA, USA). 


\section{Results and Discussion}

\subsection{UV/NO $\mathrm{NO}_{3}$ Degradation of 1,4-dioxane: The Impact of Initial Nitrate Concentration}

Degradation of 1,4-dioxane by $\mathrm{UV} / \mathrm{NO}_{3}$ followed pseudo-first order kinetics, which is characteristic of UV/AOPs, as $\mathrm{OH} \bullet$ radicals rapidly reach a steady-state concentration [24]. Figure 2 presents the degradation data for nitrate concentrations 0 (only UV) and $5 \mathrm{mg} \mathrm{N} / \mathrm{L}$ (in buffered deionized water at $\mathrm{pH}$ 7.8). Direct photolysis of 1,4-dioxane was relatively slow, due to the compound's extremely low UV light absorption [24]. Adding $5 \mathrm{mg} \mathrm{N} / \mathrm{L}$ nitrate, on the other hand, enhanced the degradation of the contaminant (reaching approximately 55\% degradation at 15 min), most likely as a result of its reaction with photo-generated $\mathrm{OH} \bullet$ [24]. The impact of initial nitrate concentration on 1,4-dioxane degradation rate is illustrated in the inset of Figure 2; here, further increasing the nitrate concentration up to $16 \mathrm{mg} \mathrm{N} / \mathrm{L}$ (the Israeli MCL in drinking water; https:/ / www.health.gov.il/English) did not result in a higher degradation rate.

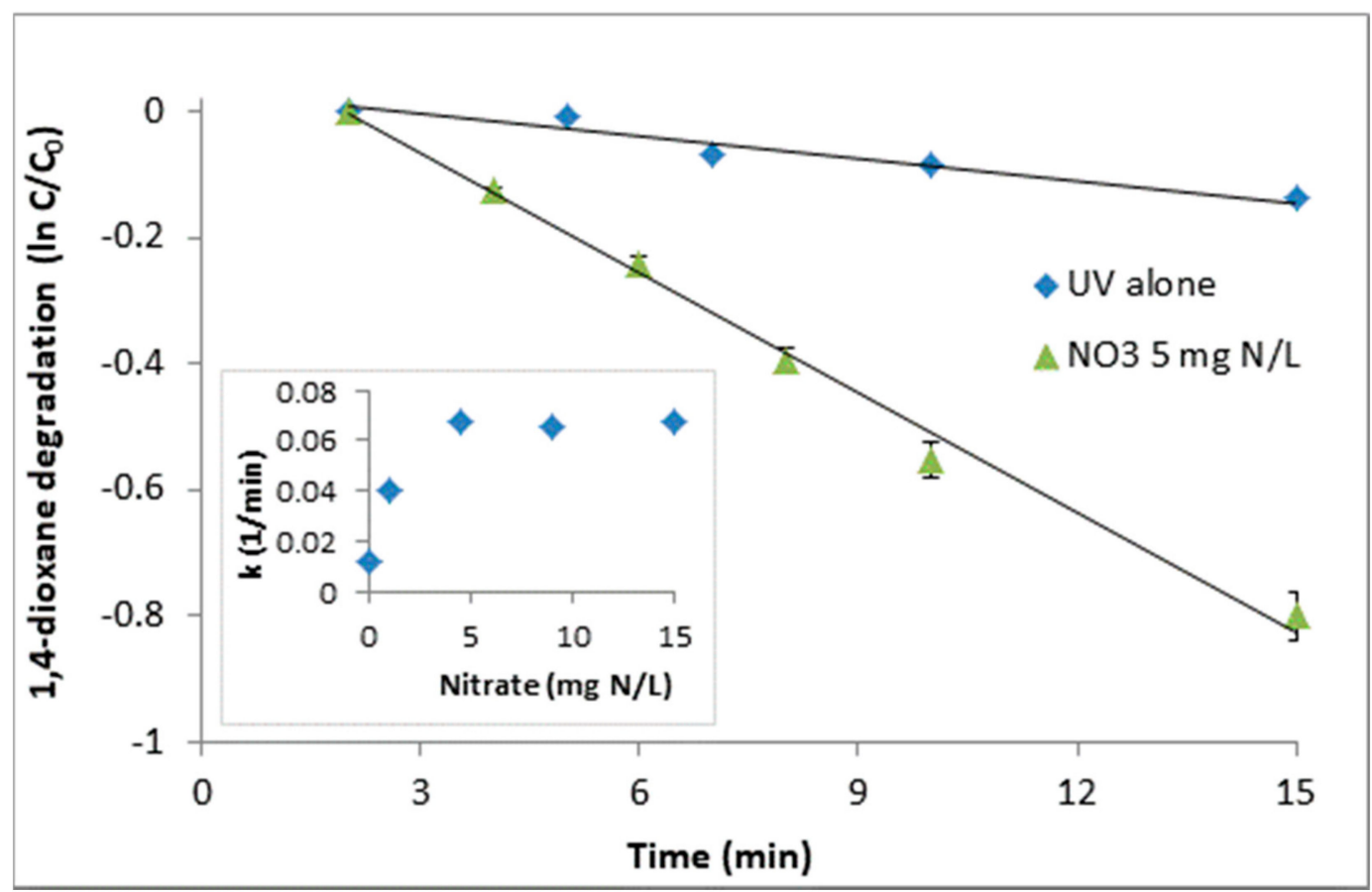

Figure 2. The degradation of 1,4-dioxane by UV alone and by UV/ $\mathrm{NO}_{3}(5 \mathrm{mg} \mathrm{N} / \mathrm{L})$. The inset presents the first-order rate constants vs. initial nitrate concentration. Experiments conducted in buffered deionized water (DI) at $\mathrm{pH} 7.8$.

The trend of 1,4-dioxane degradation rate at different nitrate levels can be explained by the changes in $\mathrm{OH} \bullet$ concentrations, measured using methylene blue (MB) as a probe (in a different set of experiments without 1,4-dioxane). Methylene blue (MB) degradation followed pseudo-first-order kinetics as follows:

$$
\ln \frac{[M B]_{t}}{[M B]_{0}}=-k_{\mathrm{OH} \bullet \mathrm{MB}}[\mathrm{OH} \bullet] t
$$

where, $k_{\mathrm{OH}} \bullet, \mathrm{MB}$ is a time-based reaction rate constant between the probe $\mathrm{MB}$ and the hydroxyl radicals $\left(k_{\mathrm{OH} \bullet \mathrm{MB}}=2.1 \times 10^{10} 1 / \mathrm{Ms}\right.$; Buxton et al. [37]).

As illustrated in Figure 3, production of $\mathrm{OH} \bullet$, measured through $\mathrm{MB}$ decay, increased rapidly with nitrate concentration, then slowed-similar to the trend observed for 1,4-dioxane. This can be explained by the fast reaction of $\mathrm{OH} \bullet$ with photo-generated nitrite $\left(k_{\mathrm{OH}} \bullet \mathrm{NO} 21 \times 10^{10} 1 / \mathrm{Ms}\right.$; [37]), decreasing the radicals' concentration and inhibiting the degradation rate 1,4-dioxane at high concentrations of nitrate [8]: 


$$
\begin{gathered}
\mathrm{NO}_{3}{ }^{-}+\mathrm{h} v \rightarrow \rightarrow \mathrm{NO}_{2}{ }^{-}, \mathrm{OH} \bullet \text {, other products } \\
\mathrm{NO}_{2}{ }^{-}+\mathrm{OH} \bullet \rightarrow \mathrm{NO}_{2}{ }^{\bullet}+\mathrm{OH}
\end{gathered}
$$

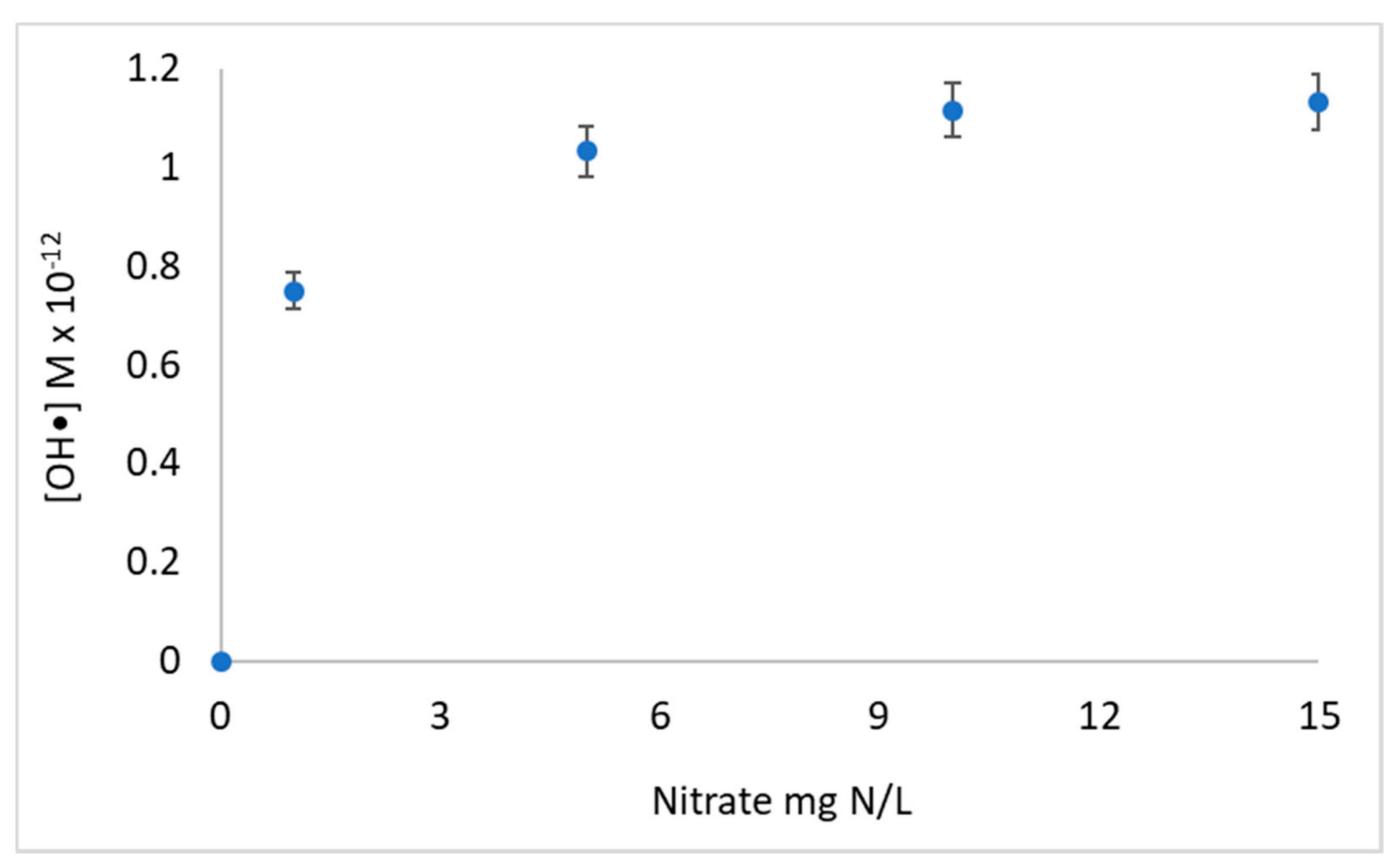

Figure 3. The concentration of $\mathrm{OH} \bullet$ during the irradiation of varying nitrate concentrations with medium pressure (MP) UV.

\subsection{Nitrate Decay and Nitrite Formation}

Nitrite is by far the most important byproduct of nitrate photolysis [6], especially at high UV doses. Figure 4 illustrates the nitrate decay and nitrite formation during $\mathrm{UV} / \mathrm{NO}_{3}$ for different initial nitrate concentrations. Nitrate concentration decreased significantly with irradiation, in parallel to the formation (and accumulation) of nitrite. The concentration of nitrite quickly reached (and in most cases overpassed) the U.S. EPA drinking water standard of $1 \mathrm{mg} \mathrm{N} / \mathrm{L}$, even at the lowest initial nitrate concentration. Previous studies found much lower nitrite concentrations during $\mathrm{UV} / \mathrm{NO}_{3}$; these studies, however, applied UV doses up to $400 \mathrm{~mJ} / \mathrm{cm}^{2}$ [28] and $700 \mathrm{~mJ} / \mathrm{cm}^{2}$ [38]. For comparison, the UV dose in our study was evaluated as approximately $3000 \mathrm{~mJ} / \mathrm{cm}^{2}$ at $6 \mathrm{~min}$ irradiation (calculated as the product of measured fluence-rate and irradiation time). Based on our results, it is clear that at high UV doses, the nitrite formation is significant and cannot be overlooked. 


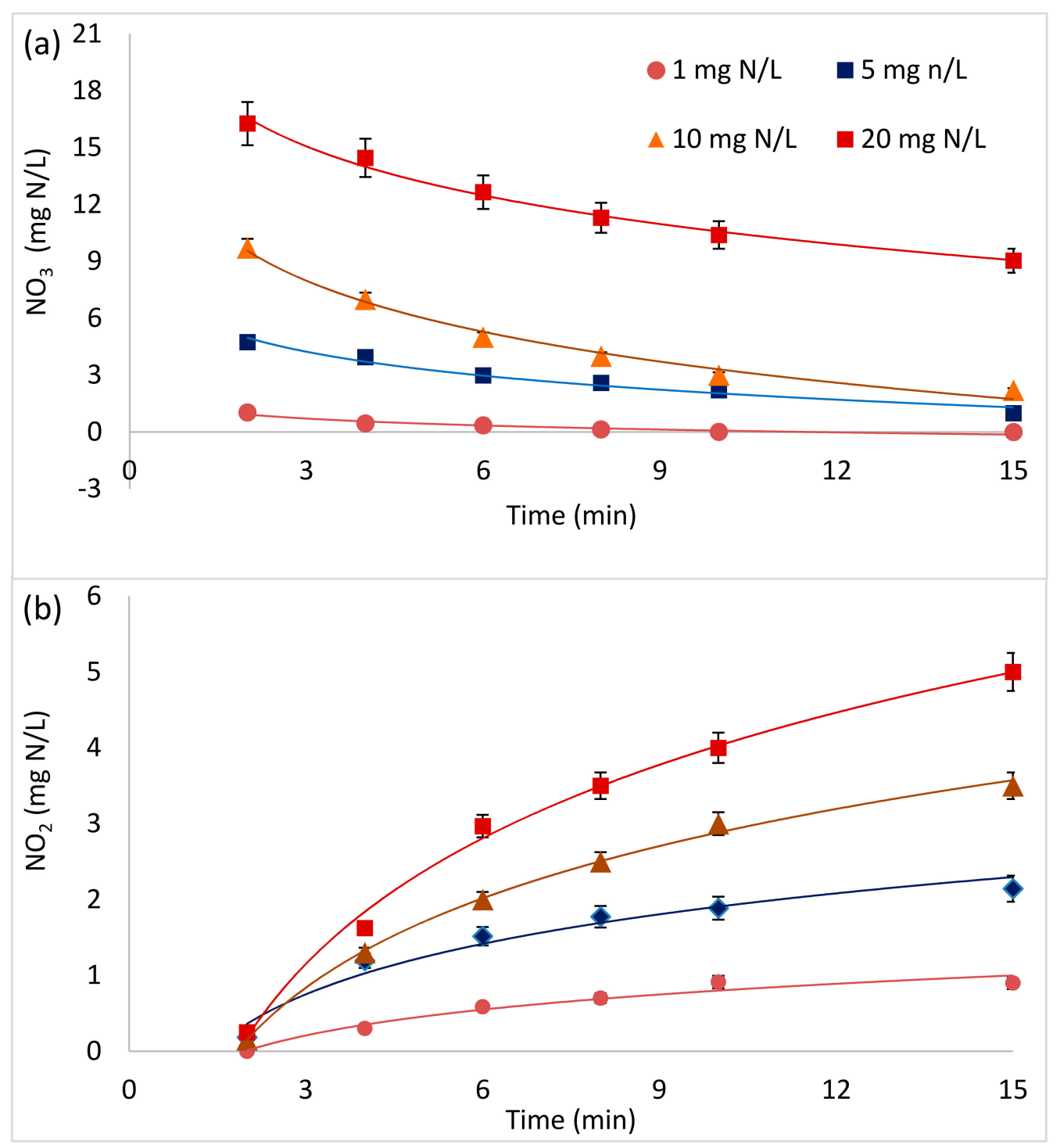

Figure 4. The nitrate decay (a) and nitrite formation (b) at different initial $\mathrm{NO}_{3}{ }^{-}$concentrations.

\subsection{Effect of Bicarbonate on the UV/NO 3 Process}

Carbonate species are ubiquitous in groundwater and are important factors in the efficiency of AOPs (due to their fast reaction with $\mathrm{OH} \bullet$ ) [39]. We examined the impact of bicarbonate on $\mathrm{UV} / \mathrm{NO}_{3}$ in the range of $0-300 \mathrm{mg} / \mathrm{L}$, typical for Israel's groundwater (Israel Water Authority; http://www.water.gov.il/). Increasing the concentration of bicarbonate up to $200 \mathrm{mg} / \mathrm{L}$ only marginally affects 1,4-dioxane degradation (Figure 5); however, at higher concentrations (300 mg/L) bicarbonate reduces the degradation rate of 1,4-dioxane by approximately $25 \%$. Carbonates concentration of $300 \mathrm{mg} / \mathrm{L}$ was determined by the US Army Corps of Engineers as the threshold for water treated by UV-AOP. Higher carbonate levels have a terminal effect on the process due to $\mathrm{OH} \bullet$ scavenging.

Additionally, increasing bicarbonate concertation lowers the nitrite formation rate, as illustrated in the inset of Figure 3. A similar phenomenon was observed by Sharpless and Linden [28], in whose study the yield of nitrite formation during $\mathrm{UV} / \mathrm{NO}_{3}$ was significantly decreased with the addition of bicarbonate (at $\mathrm{pH}$ 8). The researchers explain this trend by the reaction of $\mathrm{CO}_{2}(\mathrm{aq})$ with peroxynitrite (an intermediate in nitrite formation), preventing its transformation into nitrite. It should be noted, however, that even at the highest bicarbonate concentration examined, the nitrite level was reduced by no more than $25 \%$ and was still significantly above $1 \mathrm{mg} \mathrm{N} / \mathrm{L}$. 


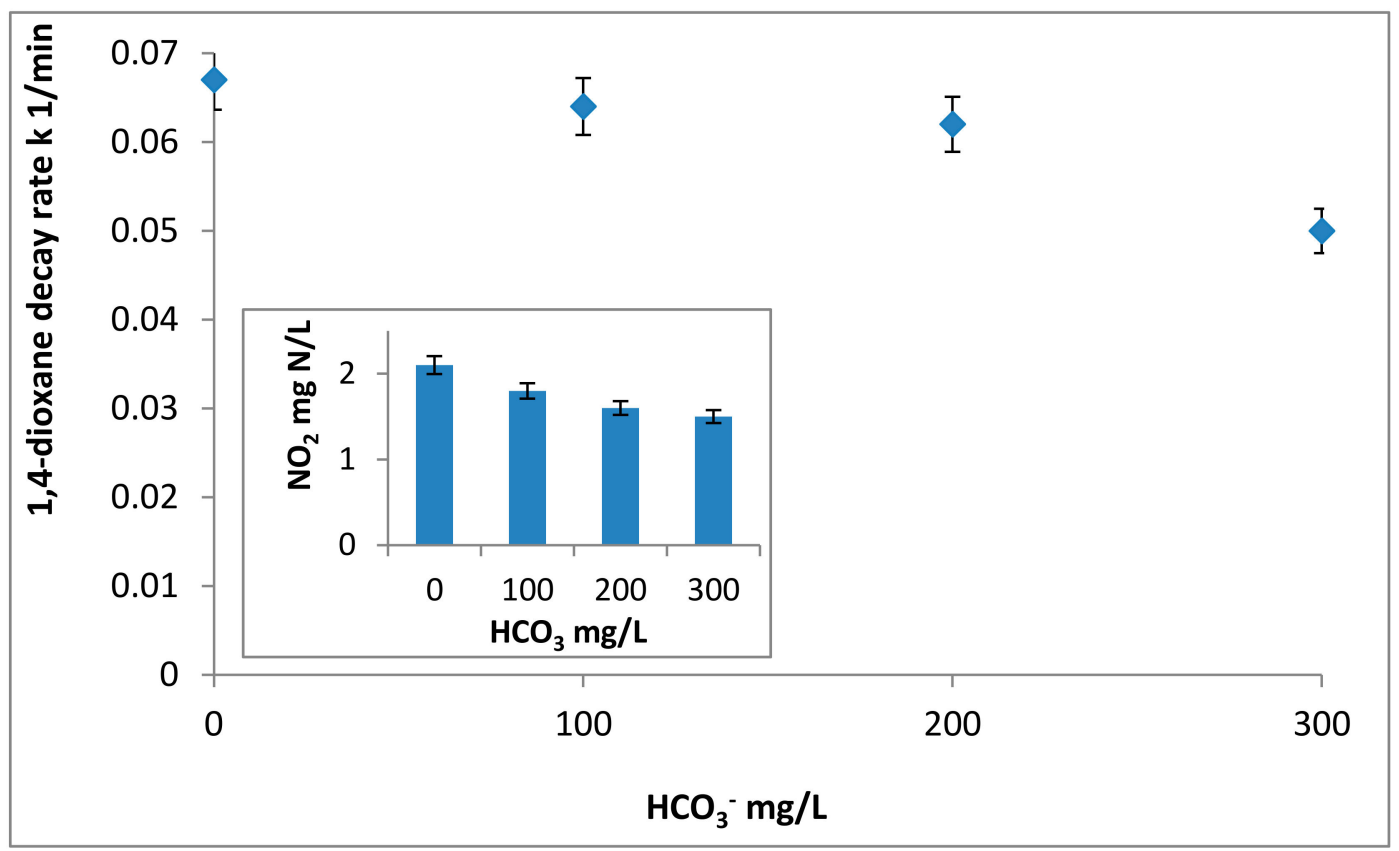

Figure 5. The rate constant of 1,4-dioxane degradation by $\mathrm{UV} / \mathrm{NO}_{3}(5 \mathrm{mg} \mathrm{N} / \mathrm{L})$, at different bicarbonate concentrations. The inset show produced nitrite concentrations in the presence of bicarbonate after 15 min of UV irradiation of nitrate $(5 \mathrm{mg} \mathrm{N} / \mathrm{L})$ and a 1,4 dioxane $(10 \mu \mathrm{M})$ containing solution.

\subsection{1,4-Dioxane Oxidation Intermediates}

Stefan and Bolton [24] previously conducted an extensive mechanistic study of 1,4-dioxane degradation by AOP. Here, we attempted to identify 1,4-dioxane intermediates and compare them to what was previously published by Stefan and Bolton (and by others). Experiments to identify 1,4-dioxane intermediates were undertaken by irradiating a sample of $10 \mathrm{mg} / \mathrm{L}$ 1,4-dioxane and $5 \mathrm{mg}$ $\mathrm{N} / \mathrm{L}$ nitrate for $15 \mathrm{~min}$. The parent compound and intermediates were then extracted by liquid-liquid extraction, and analyzed by GC/MS (Figure 6). Four major reaction intermediates were detected; of which only compound 1 could be identified with a high level of certainty as the 1,2-ethanediol diformate ester. This intermediate, which is the result of a radical chain reaction initiated by $\mathrm{OH} \bullet$ attack on 1,4-dioxane [25], is often detected during the $\mathrm{OH} \bullet$ degradation of 1,4-dioxane [24,26] and is considered less toxic than the parent compound [40]. Compounds 3 and 4 were postulated to be 1,3-dioxolane, 2-(1-methylethyl), and 2-[2-[2-methoxyethoxy]-ethoxy]-1,3-dioxalane respectively, based on their mass spectra; however, these molecular structures could not be confirmed through literature references or other means.

To evaluate the behavior of intermediate 1 , we plotted its peak area normalized to the initial peak area of 1,4-dioxane versus the reaction time (Figure 7). The concentration of the intermediate increased with time until it reached a maximum at $8 \mathrm{~min}$. Further increasing the irradiation time results in a decrease in the intermediate concentration, indicating that it is further oxidized by $\mathrm{OH} \bullet$ reactions. A similar trend was observed by others $[24,41]$, which showed that the maximum concentration of 1,2-ethanediol diformate ester does not exceed $75 \%$ of the initial concentration of 1,4-dioxane. The concentration of dissolved organic carbon (DOC) decreased by approximately $25 \%$ after $15 \mathrm{~min}$ (Figure 7), indicating that almost half of the contaminant removed was mineralized. 


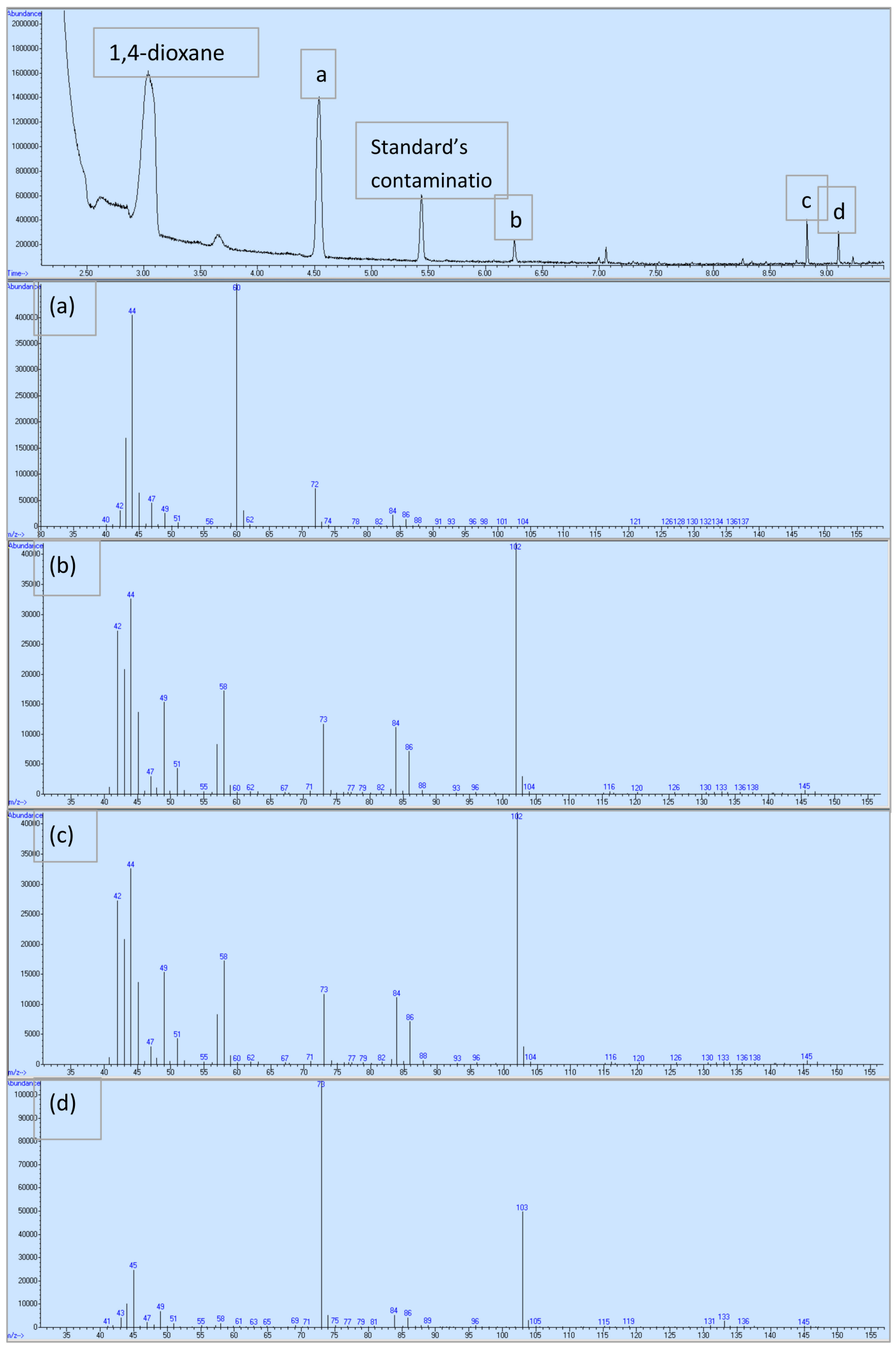

Figure 6. The MS chromatogram of the $\mathrm{UV} / \mathrm{NO}_{3}$ degradation of 1,4-dioxane (upper part) and mass spectra of the detected intermediates (parts (a-d)), taken from an experiment with $5 \mathrm{mg}$ N/L nitrate after $15 \mathrm{~min}$ (Figure 2). 


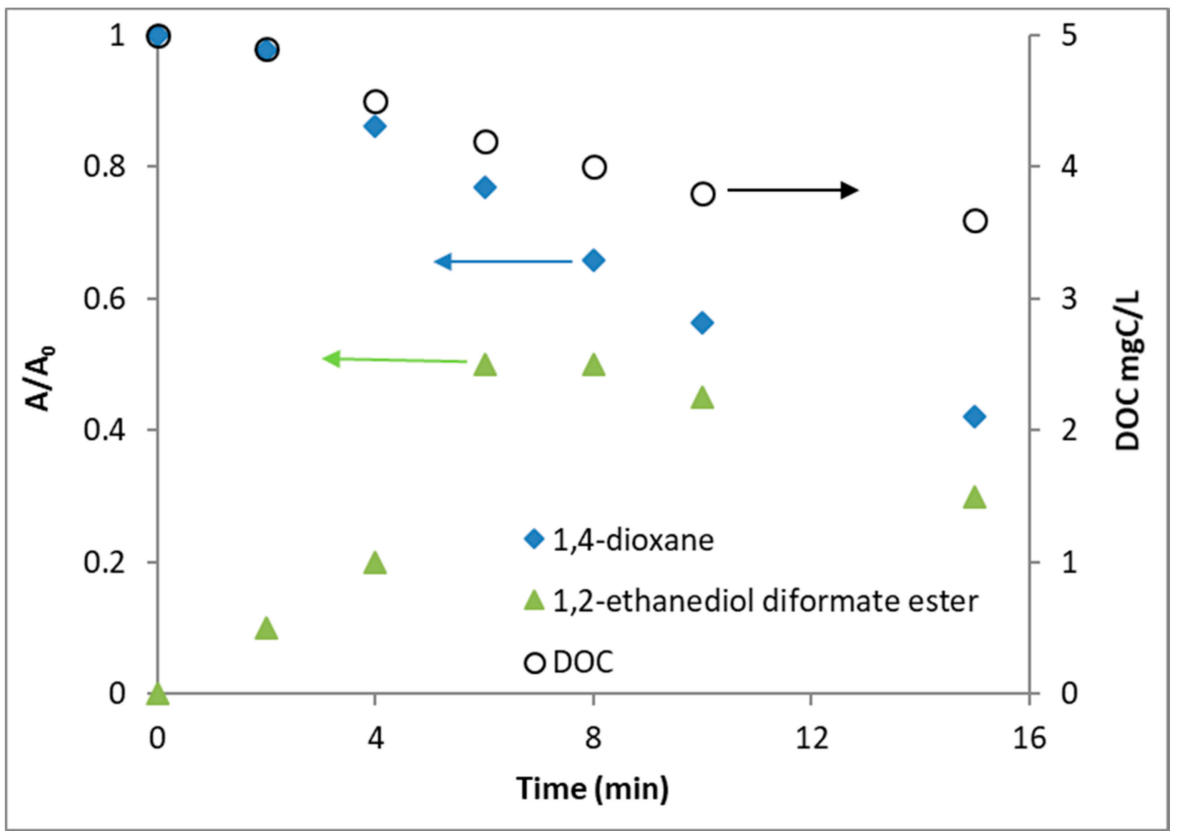

Figure 7. The MS peak areas for 1,4-dioxane and its main oxidation intermediate, normalized to the initial value of the peak area of 1,4-dioxane $(t(0))$, presented vs. time. Additionally, the DOC concentration from a separated experiment using initial 1,4-dioxane of $10 \mathrm{mg} / \mathrm{L}$ is also presented.

\subsection{Nitrite Reduction by $\mathrm{UV} / \mathrm{SO}_{3}$}

Controlling the level of nitrite during $\mathrm{UV} / \mathrm{NO}_{3}$ is imperative for any future application of the proposed process. In our case, nitrite concentration was reduced by the addition of sulfite to the $\mathrm{UV} / \mathrm{NO}_{3}$ process after $10 \mathrm{~min}$ of irradiation, to produce reducing radicals that further degrade nitrite. Preliminary experiments were conducted to determine: (i) the impact of sulfite on nitrite concentration (without UV), and (ii) the effect of sulfite addition at the beginning of irradiation. The former experiment shows that sulfite alone cannot reduce nitrite, whereas the latter results in slower degradation of 1,4-dioxane (than sulfite addition after $10 \mathrm{~min}$ ). Sulfite largely absorbs light at $<250 \mathrm{~nm}$; thus its addition at the beginning of irradiation reduces the amount of light absorbed by nitrate, leading to a lower $\mathrm{OH} \bullet$ production and slower 1,4-dioxane degradation.

Figure 8 illustrates the effect of sulfite addition on the concentration of nitrite during $\mathrm{UV} / \mathrm{NO}_{3}$, for initial nitrate levels of 1 and $5 \mathrm{mg} \mathrm{N} / \mathrm{L}$ (sulfite was added at 50 and $100 \mathrm{mg} / \mathrm{L}$, respectively). Nitrite concentration dropped by approximately $50 \%$ after five minutes from the addition of sulfite, most likely due to its reaction with the photo-sensitized reducing radicals. Degradation of 1,4-dioxane was only marginally affected by sulfite addition (results not shown). Early studies show that nitrite quickly reacts with $e_{\mathrm{aq}}{ }^{-}\left(k=4.1 \times 10^{9} 1 / \mathrm{Ms}\right.$, [37]), producing nitric oxide (NO•) and other intermediates [28]. Sulfite radicals were oxidized into (harmless) sulfate $\left(\mathrm{SO}_{4}{ }^{2-}\right)$ [7], as implied by the increase in sulfate concentration with time (Table 1).

Table 1. The concentrations of sulfite and sulfate at 12 and 15 min of irradiation.

\begin{tabular}{|c|c|c|c|c|}
\hline \multirow{2}{*}{ Initial $\mathrm{NO}_{3}$} & \multicolumn{2}{|c|}{ Sulfite (mg/L) } & \multicolumn{2}{|c|}{ Sulfate (mg/L) } \\
\hline & $12 \mathrm{~min}$ & $15 \mathrm{~min}$ & $12 \mathrm{~min}$ & $15 \mathrm{~min}$ \\
\hline $1 \mathrm{mg} \mathrm{N} / \mathrm{L}$ & $35( \pm 4)$ & $12( \pm 2)$ & $11( \pm 3)$ & $23( \pm 4)$ \\
\hline $5 \mathrm{mg} \mathrm{N} / \mathrm{L}$ & $61( \pm 7)$ & $42( \pm 5)$ & $15( \pm 2)$ & $28( \pm 5)$ \\
\hline
\end{tabular}




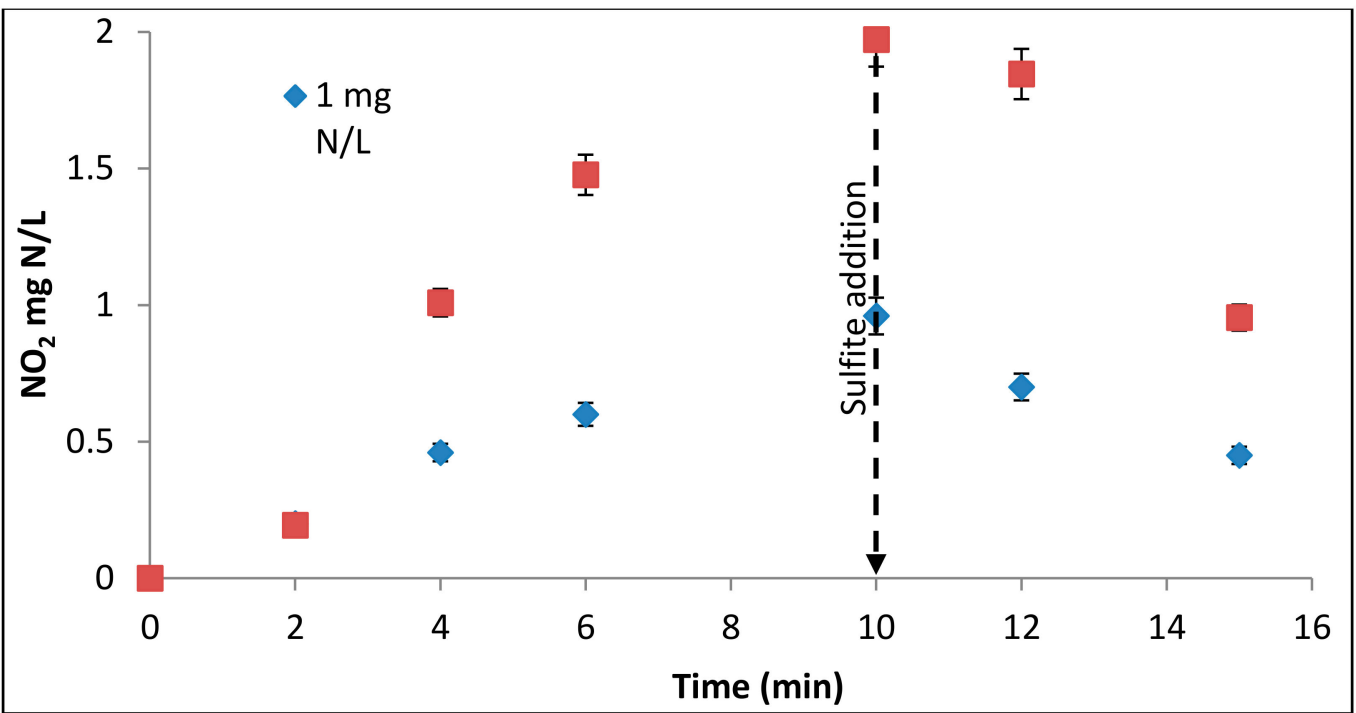

Figure 8. The nitrite concentration during $\mathrm{UV} / \mathrm{NO}_{3}$ (at initial $\mathrm{NO}_{3}{ }^{-}$concentrations 1 and $5 \mathrm{mg} \mathrm{N} / \mathrm{L}$ ). Sodium sulfite was added at $10 \mathrm{~min}$, at concentrations 50 and $100 \mathrm{mg} / \mathrm{L}$ for the low and high $\mathrm{NO}_{3}{ }^{-}$ concentrations respectively. The compound 1,4-dioxane was at $10 \mu \mathrm{M}$.

Nitrite reduction by $e_{\mathrm{aq}}{ }^{-}$can proceed via several pathways, each generating different stable end products [42-44]:

$$
\begin{gathered}
\mathrm{NO}_{2}{ }^{-}+e_{\mathrm{aq}}{ }^{-} \rightarrow \rightarrow \mathrm{NO} \cdot \text {, other intermediates }+ \text { organics } \rightarrow \text { organic nitrogen species } \\
\mathrm{NO}_{2}{ }^{-}+e_{\mathrm{aq}}{ }^{-} \rightarrow \rightarrow \mathrm{N}_{2} \mathrm{O}+e_{\mathrm{aq}}{ }^{-} \rightarrow \mathrm{N}_{2}(\mathrm{~g})+\mathrm{OH}^{-}+\mathrm{OH} \bullet \\
\mathrm{NO}_{2}{ }^{-}+e_{\mathrm{aq}}{ }^{-} \rightarrow \rightarrow \mathrm{NO}+e_{\mathrm{aq}}{ }^{-} \rightarrow \rightarrow \mathrm{NH}_{2} \mathrm{OH}+e_{\mathrm{aq}}{ }^{-} \rightarrow \mathrm{NH}_{3}
\end{gathered}
$$

To elucidate the dominant mechanism, we conducted a UV/NO $\mathrm{NO}_{3}+\mathrm{SO}_{3}{ }^{2-}$ experiment (initial $\mathrm{NO}_{3}{ }^{-}$concentrations $=1 \mathrm{mg} \mathrm{N} / \mathrm{L}$ ) in organic-free water (i.e., without 1,4-dioxane addition), while monitoring nitrite, nitrate, and ammonia. Concentrations of nitrate and nitrite follow the trends observed earlier; nitrate concentration steadily decreases, while nitrite concentration increases at first, then decreases following $\mathrm{SO}_{3}{ }^{2-}$ addition. Ammonia concentration remained below detection limit $(<0.1 \mathrm{mg} \mathrm{N} / \mathrm{L})$ in all measured samples. Based on these results, we suggest that the main product of nitrite reduction by $e_{\mathrm{aq}}{ }^{-}$is nitrogen gas. It should be noted, however, that when organic matter is present, the production of organic nitrogen species may occur.

\subsection{Implications for Groundwater Remediation}

Nitrate $\left(\mathrm{NO}_{3}{ }^{-}\right)$and 1,4-dioxane are two of the most important groundwater contaminants in Israel (and worldwide), responsible for most disqualifications of groundwater wells in the coastal aquifer of the country (Israel Water Authority). While treating nitrate contamination is feasible but costly (usually through ion exchange or biological processes), removing 1,4-dioxane from groundwater is much more challenging. 1,4-dioxane is non-biodegradable and cannot be removed by sorption or air-stripping, due to its high solubility and low vapor pressure [25]. Moreover, 1,4-dioxane is poorly removed during reverse osmosis desalination [45] and conventional AOPs (for example, $\mathrm{UV} / \mathrm{H}_{2} \mathrm{O}_{2}$ ) are typically too costly to be applied on a large scale [27].

We demonstrate a potentially cost-effective treatment process, which is able to simultaneously remove nitrate and 1,4-dioxane from groundwater. Our results imply that MP UV irradiation at relatively high doses with the addition of sulfite at an optimized time-point has the potential to degrade nitrate and 1,4-dioxane (and possibly other organic contaminants) while keeping the nitrite level below its MCL. The produced water is expected to have elevated concentrations of sulfate. 
This ion, however, is relatively harmless with mostly an organoleptic effect (MCL of $250 \mathrm{mg} / \mathrm{L}$; Israel Ministry of Health). A schematic representation of the proposed treatment is illustrated in Figure 9.

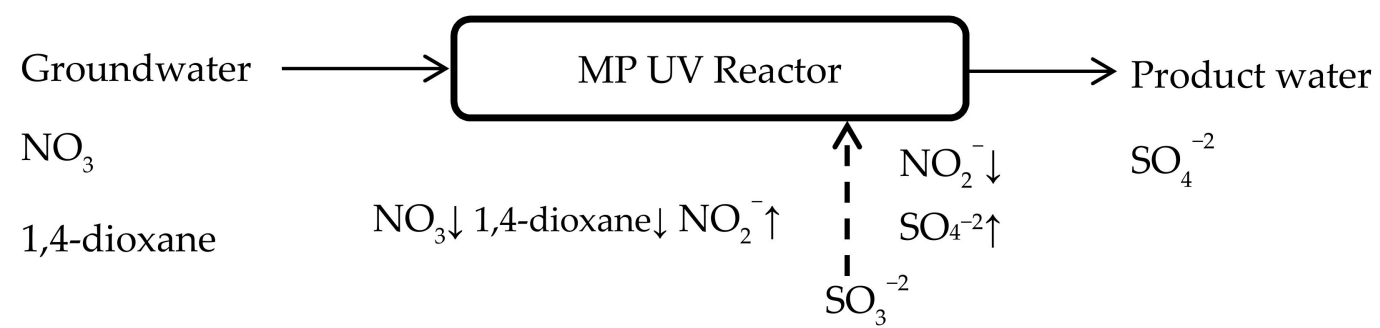

Figure 9. The schematic representation of the $\mathrm{UV} / \mathrm{NO}_{3}+\mathrm{SO}_{3}{ }^{2-}$ treatment.

In evaluating the applicability of the proposed process, some additional points should be kept in mind: (i) the process is only valid for groundwater containing both organic contaminants and nitrate (preferably at $>5 \mathrm{mg} \mathrm{N} / \mathrm{L}$ ), (ii) extended work should be conducted, mainly with regard to optimization sulfite concentration and injection point, and (iii) the impact of other water constituents should be evaluated. For example, nitrate photolysis in the presence of aromatic compounds may produce potent nitroaromatics [46]. While these compounds will likely be degraded at the high UV doses applied $\left(>3000 \mathrm{~mJ} / \mathrm{cm}^{2}\right)$, their potential formation should not be overlooked.

\section{Conclusions}

Groundwater is often contaminated by inorganic ions such as nitrate, and organic chemicals such chlorinated solvents and 1,4-dioxane. Removing these contaminants requires the implementation of numerous treatments, which are often not cost-effective. In the present study we propose to use UV light in combination with in-situ nitrate to degrade organic groundwater contaminants, specifically 1,4-dioxane. Furthermore, we show that concentration of nitrite, a hazardous intermediate of nitrate photolysis, can be controlled through the injection of sulfite and the production of reducing radicals. Altogether, this study presents a proof-of-concept for a new cost-effective groundwater treatment: UV sensitization of in situ nitrate (to oxidize 1,4-dioxane and other organics) followed by UV sensitization of (added) sulfite to reduce photo-generated nitrite. This treatment simultaneously remove 1,4-dioxane and nitrate, while keeping nitrite below MCL.

Author Contributions: Conceptualization, Y.L.; methodology, Y.L.; formal analysis, Y.L.; investigation, A.D. and D.E.; writing—original draft preparation, Y.L.

Funding: This research received no external funding.

Acknowledgments: The authors would like to thank Dror Avisar and Aviv Kaplan for thier technical assistance with the GC instrument.

Conflicts of Interest: The authors declare no conflicts of interest.

\section{References}

1. Zafiriou, O.C.; Bonneau, R. Wavelength-dependent quantum yield of $\mathrm{OH}$ radical formation from photolysis of nitrite ion in water. Photochem. Photobiol. 1987, 45, 723-727. [CrossRef]

2. Zepp, R.G.; Holgne, J.; Bader, H. Nitrate-induced photooxidation of trace organic chemicals in water. Environ. Sci. Technol. 1987, 21, 443-450. [CrossRef] [PubMed]

3. Andreozzi, R.; Marotta, R.; Paxéus, N. Pharmaceuticals in STP effluents and their solar photodegradation in aquatic environment. Chemosphere 2003, 50, 1319-1330. [CrossRef]

4. Daniels, M.; Meyers, R.V.; Belardo, EV. Photochemistry of the aqueous nitrate system. I. Excitation in the 300-m.mu. band. J. Phys. Chem. 1968, 72, 389-399. [CrossRef]

5. Shuali, U.; Ottolenghi, M.; Rabani, J.; Yelin, Z. On the photochemistry of aqueous nitrate solutions excited in the 195-nm band. J. Phys. Chem. 1969, 73, 3445-3451. [CrossRef] 
6. Mack, J.; Bolton, J.R. Photochemistry of nitrite and nitrate in aqueous solution: A review. J. Photochem. Photobiol. A Chem. 1999, 128, 1-13. [CrossRef]

7. Vellanki, B.P.; Batchelor, B.; Abdel-Wahab, A. Advanced reduction processes: A new class of treatment processes. Environ. Eng. Sci. 2013, 30, 264-271. [CrossRef] [PubMed]

8. Keen, O.S.; Love, N.G.; Linden, K.G. The role of effluent nitrate in trace organic chemical oxidation during UV disinfection. Water Res. 2012, 46, 5224-5234. [CrossRef] [PubMed]

9. Lester, Y.; Ferrer, I.; Thurman, E.M.; Linden, K.G. Demonstrating sucralose as a monitor of full-scale UV / AOP treatment of trace organic compounds. J. Hazard Mater. 2014, 280, 104-110. [CrossRef] [PubMed]

10. Gu, B.; Ge, Y.; Chang, S.X.; Luo, W.; Chang, J. Nitrate in groundwater of China: Sources and driving forces. Glob. Environ. Chang. 2013, 23, 1112-1121. [CrossRef]

11. Haran, M.; Samuels, R.; Uri Mingelgrin, S.G. Quality indicators of the state of chemical pollution in Israel. Isr. J. Chem. 2002, 42, 119-132. [CrossRef]

12. Zhou, Z. A Global Assessment of Nitrate Contamination in Groundwater-Internship report. International Groundwater Resources Assessment Center 2015. Available online: https:/ / www.un-igrac.org/resource/ global-assessment-nitrate-contamination-groundwater (accessed on 20 January 2015).

13. Shalev, N.; Burg, A.; Gavrieli, I.; Lazar, B. Nitrate contamination sources in aquifers underlying cultivated fields in an arid region-The Arava Valley, Israel. Appl. Geochem. 2015, 63, 322-332. [CrossRef]

14. Nolan, B.T.; Ruddy, B.C.; Hitt, K.J.; Helsel, D.R. Risk of nitrate in groundwaters of the United States-A national perspective. Environ. Sci. Technol. 1997, 31, 2229-2236. [CrossRef]

15. Spalding, R.F.; Exner, M.E. Occurrence of Nitrate in Groundwater-A Review. J. Environ. Qual. 1993, $22,392$. [CrossRef]

16. Adamson, D.T.; Mahendra, S.; Walker, K.L.; Rauch, S.R.; Sengupta, S.; Newell, C.J. A Multisite Survey to Identify the Scale of the 1,4-Dioxane Problem at Contaminated Groundwater Sites. Environ. Sci. Technol. Lett. 2014, 1, 254-258. [CrossRef]

17. Stepien, D.K.; Diehl, P.; Helm, J.; Thoms, A.; Püttmann, W. Fate of 1,4-dioxane in the aquatic environment: From sewage to drinking water. Water Res. 2014, 48, 406-419. [CrossRef] [PubMed]

18. Pye, V.I.; Patrick, R. Ground Water Contamination in the United States. Science 1983, 221, 713-718. [CrossRef] [PubMed]

19. Mohr, T.K.G. Environmental Investigation and Remediation: 1,4-Dioxane and other Solvent Stabilizers; CRC Press: Boca Roca, FL, USA, 2010.

20. Abe, A. Distribution of 1,4-dioxane in relation to possible sources in the water environment. Sci. Total Environ. 1999, 227, 41-47. [CrossRef]

21. U.S. Environmental Protection Agency; Integrated Risk Information System (IRIS). 1,4-Dioxane; National Center for Environmental Assessment: Washington, DC, USA, 1999.

22. 1,4-Dioxane in Drinking-Water. Background Document for Development of WHO Guidelines for Drinking-Water Quality. Available online: http:/ / www.who.int/water_sanitation_health/dwq/chemicals/ 14dioxane0505.pdf (accessed on 12 August 2005).

23. Otto, M.; Nagaraja, S. Treatment technologies for 1,4-Dioxane: Fundamentals and field applications. Remediation 2007, 17, 81-88. [CrossRef]

24. Stefan, M.I.; Bolton, J.R. Mechanism of the degradation of 1,4-dioxane in dilute aqueous solution using the UV/hydrogen peroxide process. Environ. Sci. Technol. 1998, 32, 1588-1595. [CrossRef]

25. Vescovi, T.; Coleman, H.M.; Amal, R. The effect of $\mathrm{pH}$ on UV-based advanced oxidation technologies-1,4-Dioxane degradation. J. Hazard Mater. 2010, 182, 75-79. [CrossRef] [PubMed]

26. Alvarez-Corena, J.R.; Bergendahl, J.A.; Hart, F.L. Advanced oxidation of five contaminants in water by $\mathrm{UV} / \mathrm{TiO}_{2}$ : Reaction kinetics and byproducts identification. J. Environ. Manag. 2016, 181, 544-551. [CrossRef] [PubMed]

27. Rosenfeldt, E.J.; Linden, K.G. The ROH, UV concept to characterize and the model UV $/ \mathrm{H}_{2} \mathrm{O}_{2}$ process in natural waters. Environ. Sci. Technol. 2007, 41, 2548-2553. [CrossRef]

28. Sharpless, C.M.; Linden, K.G. UV photolysis of nitrate: Effects of natural organic matter and dissolved inorganic carbon and implications for UV water disinfection. Environ. Sci. Technol. 2001, 35, 2949-2955. [CrossRef] [PubMed] 
29. Duan, Y.; Batchelor, B. Impacts of natural organic matter on perchlorate removal by an advanced reduction process. J. Environ. Sci. Health Part A Toxic Hazardous Subst. Environ. Eng. 2014, 49, 731-740. [CrossRef] [PubMed]

30. Vellanki, B.P.; Batchelor, B. Perchlorate reduction by the sulfite/ultraviolet light advanced reduction process. J. Hazard Mater. 2013, 262, 348-356. [CrossRef] [PubMed]

31. Liu, X.; Vellanki, B.P.; Batchelor, B.; Abdel-Wahab, A. Degradation of 1,2-dichloroethane with advanced reduction processes (ARPs): Effects of process variables and mechanisms. Chem. Eng. J. 2014, 237, 300-307. [CrossRef]

32. Xiao, Q.; Yu, S.; Li, L.; Wang, T.; Liao, X.; Ye, Y. An overview of advanced reduction processes for bromate removal from drinking water: Reducing agents, activation methods, applications and mechanisms. J. Hazard Mater. 2017, 324, 230-240. [CrossRef] [PubMed]

33. Dong, X.; Li, C.; Zheng, W.; Wang, G. Degradation of Polybrominated Aiphenyl Ethers in a UV Advanced Reduction Process with Different Reducing Agents. IOP Conf. Ser. Earth Environ. Sci. 2018, 113. [CrossRef]

34. Bensalah, N.; Nicola, R.; Abdel-Wahab, A. Nitrate removal from water using UV-M/S2O42-advanced reduction process. Int. J. Environ. Sci. Technol. 2014, 11, 1733-1742. [CrossRef]

35. Goldstein, S.; Rabani, J. Actinometers Based on $\mathrm{NO}_{3}{ }^{-}$and $\mathrm{H}_{2} \mathrm{O}_{2}$ Excitation: Applications for Industrial Photoreactors. Environ. Sci. Technol. 2008, 42, 3248-3253. [CrossRef] [PubMed]

36. Draper, W.M.; Dhoot, J.S.; Remoy, J.W.; Perera, S.K. Trace-level determination of 1,4-dioxane in water by isotopic dilution GC and GC-MS. Analyst 2000, 125, 1403-1408. [CrossRef] [PubMed]

37. Buxton, G.V.; Greenstock, C.L.; Helman, W.P.; Ross, A.B. Critical Review of rate constants for reactions of hydrated electrons, hydrogen atoms and hydroxyl radicals $(\bullet \mathrm{OH} / \bullet \mathrm{O})-$ in Aqueous Solution. J. Phys. Chem. Ref. Data 1988, 17, 513-886. [CrossRef]

38. Peldszus, S.; Andrews, S.A.; Souza, R.; Smith, F.; Douglas, I.; Bolton, J.; Huck, P.M. Effect of medium-pressure UV irradiation on bromate concentrations in drinking water, a pilot-scale study. Water Res. 2004, 38, 211-217. [CrossRef] [PubMed]

39. Wols, B.A.; Hofman-Caris, C.H.M. Review of photochemical reaction constants of organic micropollutants required for UV advanced oxidation processes in water. Water Res. 2012, 46, 2815-2827. [CrossRef] [PubMed]

40. Li, W.; Elvis, X.; Schlenk, D.; Haizhou, L. Cyto- and geno-toxicity of 1,4-dioxane and its transformation products during ultraviolet-driven advanced oxidation processes. Environ. Sci. Water Res. Technol. 2018, 4, 1213. [CrossRef]

41. Maurino, V.; Calza, P.; Minero, C.; Pelizzetti, E.; Vincenti, M. Light-assisted 1,4-dioxane degradation. Chemosphere 1997, 35, 2675-2688. [CrossRef]

42. Gonzalez, M.G.; Oliveros, E.; Wörner, M.; Braun, A.M. Vacuum-ultraviolet photolysis of aqueous reaction systems. J. Photochem. Photobiol. C Photochem. Rev. 2004, 5, 225-246. [CrossRef]

43. Li, X.; Ma, J.; Liu, G.; Fang, J.; Yue, S.; Guan, Y.; Chen, L.; Liu, X. Efficient reductive dechlorination of monochloroacetic acid by sulfite/UV process. Environ. Sci. Technol. 2012, 46, 7342-7349. [CrossRef] [PubMed]

44. Sun, Z.; Zhang, C.; Zhao, X.; Chen, J.; Zhou, Q. Efficient photoreductive decomposition of N-nitrosodimethylamine by UV/iodide process. J. Hazard Mater. 2017, 329, 185-192. [CrossRef] [PubMed]

45. Curry, M.A. 1,4 dioxane removal from groundwater using point-of-entry water treatment techniques. Master's Theses, University of New Hampshire, Durham, NH, USA, September 2012.

46. Dzengel, J.; Theurich, J.; Bahnemann, D.W. Formation of nitroaromatic compounds in advanced oxidation processes: Photolysis versus photocatalysis. Environ. Sci. Technol. 1999, 33, 294-300. [CrossRef]

(C) 2018 by the authors. Licensee MDPI, Basel, Switzerland. This article is an open access article distributed under the terms and conditions of the Creative Commons Attribution (CC BY) license (http://creativecommons.org/licenses/by/4.0/). 